\title{
Neuroprotective Effect of Dexamethasone on the Morphology of the Irradiated Post Natal Developing Cerebellum of Wistar Rat (Rattus norvegicus)
}

\author{
Efecto Neuroprotector de la Dexametasona sobre la Morfología del Cerebelo Postnatal \\ en Desarrollo Irradiado de Rata Wistar (Rattus norvegicus)
}

${ }^{* *}$ Malomo, A. O.; ***Ekpo, O. E.; "Imosemi, I. O.; "Owoeye, O.; "Osuagwu, F. C.; "***Avwioro, O. G. \& "Shokunbi, M.T.

MALOMO, A. O.; EKPO, O. E.; IMOSEMI, I. O.; OWOEYE, O.; OSUAGWU, F. C.; AVWIORO, O. G. \& SHOKUNBI, M. T. Neuroprotective effect of dexamethasone on the morphology of the irradiated post natal developing cerebellum of wistar rat (Rattus norvegicus). Int. J. Morphol., 24(2):221-229, 2006.

SUMMARY: The neuroprotective effect of dexamethasone on the irradiated postnatal developing cerebellum of Wistar rat was studied. Seventy-five (day 1 old) neonates were separated into three groups; control group receiving no drug and no irradiation, irradiated group, and irradiated and dexamethasone group in which the dexamethasone was administered one hour before exposure to 5Gray (5Gy) of gamma rays. On complete exposure to the various interventions, the cerebellar tissues of animals from each group on days 5, 9, 14, 21 and 25 were processed for histological and histomorphometric studies.

The result of the study showed that irradiation alone significantly reduced the thickness of the external granular layer (EGL) on day 5 and 14 at $\mathrm{P}<0.05$, molecular layer (ML) on days 5, 9, 14 and 21 at $\mathrm{P}<0.05$ and the granule layer (GL) on days 5, 9, 14 and 25 at $\mathrm{P}<0.05$. When dexamethasone was combined with irradiation, a thicker and significantly different EGL on days 5, 9 and 14, ML on days 5, 14 and 21 , and GL on days 5 and 14 was observed compared with the irradiated group at $\mathrm{P}<0.05$. The Purkinje cell (PC) diameter even though was significantly reduced in the irradiated group on days 14 and 21, was not significantly different when dexamethasone was administered to the irradiated animals on days 5, 9, 14, 21 and 25 at $\mathrm{p}>0.05$.

Histologically, the cells of the ML in the irradiated group on days 9 and 14 were heavily gliosed compared to the mildly gliosed control, and the irradiated and dexamethasone groups. There was distortion of the PC monolayer with some cells found in either the ML or GL in the irradiated group on days 5, 9, 14 and 25.

From the result of the study, administration of $0.005 \mathrm{ml}$ dexamethasone intraperitoneallyone hour before exposure to irradiation appeared to protect the developing rat cerebellum against irradiation injury as seen when compared with the controls.

KEY WORDS: Morphology; Irradiation; Dexamethasone; Developing cerebellum.

\section{INTRODUCTION}

The diagnosis of certain ailments may require exposure to radiation and in other cases; irradiation may be used for therapeutic purposes. Exposure to irradiation at various doses could cause malformation in certain developing body organs especially when exposed during critical periods of development (Moore \& Persaud, 1998). Such malformations could reflect in the gross and microscopic appearances of the affected organs in the mature organisms.
The teratogenicity of ionizing radiation is well documented and it is well recognized that microcephaly and spinal bifida etc., may result from treating pregnant women with large doses of irradiation (Sadhler, 1995). Studies revealed that irradiation alters cell membrane permeability, affects cell organelles, causes cleavage delay and affects mitosis at prophase stage (Grosch \& Hopwood, 1979), and that the neural tissues are known to be particularly radiosensitive (Schull, 1995).

* Department of Anatomy, College of Medicine University of Ibadan, Ibadan, Nigeria.

** Department of Surgery, College of Medicine University of Ibadan, Ibadan, Nigeria.

*** Department of Anatomy, Ladoke Akintola University of Technology, Ogbomoso, Nigeria.

*****: Department of Histopathology, School of Medical Laboratory Sciences, Obafemi Awolowo University Teaching Hospital, Ile-Ife, Nigeria. 
Hiranuma et al. (2000) reported that pregnant mice exposed to 4Gy dose of whole body $\mathrm{x}$-irradiation on day 12.5 of gestation was found to inhibit cell proliferation and caused apoptosis, which resulted in a high (91\%) incidence of palatal clefting in their offspring. In the nervous system, cell death induced by ionizing radiation in the brain of young rat was found to have morphological characteristics of apoptosis, to be mediated by protein synthesis and associated with internucleosomal desoxynucleic acid (DNA) fragmentation (Ferrer, 1996). Also, expression of two neuropeptides (substance $\mathrm{P}$ and enkephalin), in the rat laryngeal nerves, was found to be influenced by a $6-8$ Gy dose of irradiation given for five days (Lidegran et al., 1995).

A focal low dose $\mathrm{x}$-irradiation of the cerebellum after birth selectively interferes with acquisition of the full complement of the granule cells, resulting in microneuronal hypoplasia (Altman, 1987), and there was abnormal neural organization in which immature characteristics, such as distorted arrangement of the glomeruli and incomplete circuitry formation are retained in the adult rat (Sugihara, 2000). Such rats were found to be unable to accurately learn a spatial task and suffered memory impairment (Le Marec et al., 1997). Partial destruction of the granule cell population as well as a significant increase in Purkinje cell dendritic growth in young Lurcher mice exposed to $\mathrm{x}$ irradiation was reported by (Doughty et al., 1999).

Dexamethasone is purely a corticosteroid with marked anti-inflammatory and anti-allergic properties. It is a catabolic steroid, which breaks downstored fat, sugar and protein used as fuel in times of stress (Brooks, 2001). The anti-inflammatory function of dexamethasone in joint pain, itchy skin, immune suppression effect, cancer chemotherapy, treatment of central nervous system disorder, treatment of shock and reduction of blood calcium levels in certain medical conditions where calcium level is dangerously high are well documented (Brooks).

For effective management of certain disease conditions, combination of appropriate doses of various therapeutic agents may be required. This could lead to observable effects on the gross and microscopic anatomy of especially developing body organs, hence this research.

\section{MATERIALS AND METHOD}

Seventy-five (75) neonatal (day 1) rats of Wistar strain were obtained from the animal house of the Department of Anatomy, University of Ibadan. The rats were divided into three groups (control, irradiation only, and combination of irradiation and dexamethasone groups) of twenty-five animals each. The twenty-five animals were subdivided into five groups (post-natal days 5, 9, 14, 21 and 25) of five animals each.

\section{Grouping of animals:}

Group I : Control group, no drug and no irradiation.

Group II : Irradiation group only.

Group III : Irradiation and dexamethasone group.

Administration of interventions. This was done on postnatal day 1 . Group I animals received physiological saline. Group II animals received 5Gy dose from a cobalt 60 unit source of radiation in a container of field size (Fs), $9 \mathrm{~cm} \mathrm{x}$ $12 \mathrm{~cm}$ with an equivalent square area (ESA) of $10.3 \mathrm{~cm}^{3}$ over a period of 9 minutes 15 seconds. Group III animals received in addition to irradiation, $0.005 \mathrm{ml}$ of $4 \mathrm{mg} / \mathrm{ml}$ standard dexamethasone preparation intraperitoneally with an insulin needle.

After the administration of the intervention was completed, the animals were killed by cervical dislocation and the cerebellum of days 5, 9, 14, 21 and 25 dissected out, rinsed in normal saline and fixed in $10 \%$ formol saline.

Parameters studied. The cerebellar tissues were processed through paraffin wax embedding technique and stained in Haematoxylin and Eosin (HE) solution. The following parameters were studied:

I. Thickness of the layers of the cerebellar cortex using a microscope with a graticule attached to the eyepiece.

II. Mean diameter / size of the Purkinje cell using the same microscope as in (I) above and.

III. Histological changes in the cerebellar cytoarchitecture.

Statistical analysis. The Student t-Test statistics was employed to calculate the mean, standard error of mean and the level of significance using the SPSS soft ware for Windows.

\section{RESULTS}

During the experiment, it was observed that the skin of the neonates following irradiation was fragile and thin, their eyeballs were opaque and protruded and a high mortality rate was recorded probably, due to rejection for hours by their mothers. 
The histomorphometric studies revealed that a reduction in the external granular layer (EGL) in the irradiated group was observed on days 5 and 14 (26.5 \pm $0.25 \mu \mathrm{m}$ and $19.4 \pm 0.66 \mu \mathrm{m}$, respectively) as compared with the control group $(28.2 \pm 0.19 \mu \mathrm{m}$ and $22.0 \pm 0.52 \mu \mathrm{m}$ respectively). These were significant at $p<0.05$. No significant difference in the EGL was observed between the control group, and the irradiated and dexamethasone group on days 5, 9 and 14 at $p>0.05$. However, a thicker and significantly different EGL was seen in the irradiated and dexamethasone group when compared with the irradiated group on days 5 and 14 at $\mathrm{p}<0.05$ (Table I).

A reduction in the mean thickness of the molecular layer (ML) was observed in the irradiated group on days 5, 9, 14 and 21, compared with the control group. These were significantly tested at $p<0.05$. No significant difference at $p>0.05$ was observed between the control, and the irradiated and dexamethasone groups on days 5, 9 and 25. The ML was thicker and significantly different in the irradiated and dexamethasone group compared with the irradiated group at $\mathrm{P}<<0.05$ on days 5, 14 and 21 (Table II).

The mean thickness of the granule layer (GL) in the irradiated group was significantly reduced on days 5 , 9,14 and 25 compared with the control group at $\mathrm{p}<0.05$. The GL of the control group, and the irradiated and dexamethasone group on days 21 and 25 were not significantly different at $p>0.05$. Meanwhile, a significantly thicker GL was seen in the irradiated and dexamethasone group on days 5 and 14 compared with the irradiated group at $\mathrm{p}<0.05$ (Table III).

Table I. Mean thickness of the EGL (mean \pm SEM) in micrometer $(\mu \mathrm{m})$.

\begin{tabular}{lccc}
\hline Days / Group & $\mathbf{5}$ & $\mathbf{9}$ & $\mathbf{1 4}$ \\
Control & $28.2 \pm \mathbf{0 . 1 9}$ & $24.7 \pm 1.02$ & $22.0 \pm 0.52$ \\
Irrad. & $26.5 \pm 0.25$ & $20.0 \pm 1.51$ & $19.4 \pm 0.66$ \\
$\mathbf{p}$ - value & $\mathbf{0 . 0 0 3}$ & $\mathbf{0 . 0 6 5}$ & $\mathbf{0 . 0 0 6}$ \\
Control & $28.2 \pm 0.19$ & $24.7 \pm 1.02$ & $22.0 \pm 0.52$ \\
Irrad. and dexa. & $28.0 \pm 0.43$ & $24.0 \pm 0.82$ & $21.2 \pm 0.65$ \\
$\mathbf{P}$ - value & $\mathbf{0 . 0 6 4}$ & $\mathbf{0 . 6 6 7}$ & $\mathbf{0 . 3 2 2}$ \\
Irrad. & $26.5 \pm \mathbf{0 . 2 5}$ & $20.0 \pm 1.51$ & $19.4 \pm 0.66$ \\
Irrad. and dexa. & $28.0 \pm 0.43$ & $24.0 \pm 0.82$ & $21.2 \pm 0.65$ \\
$\mathbf{p}-$ value & $\mathbf{0 . 0 0 3}$ & $\mathbf{0 . 0 8 5}$ & $\mathbf{0 . 0 3 9}$ \\
\hline
\end{tabular}

Table II. Mean thickness of the ML (mean SEM) in micrometer $(\mu \mathrm{m})$.

\begin{tabular}{lccccc}
\hline Days / Group & $\mathbf{5}$ & $\mathbf{9}$ & $\mathbf{1 4}$ & $\mathbf{2 1}$ & $\mathbf{2 5}$ \\
Control & $34.5 \pm 0.94$ & $40.3 \pm 0.64$ & $109.9 \pm 0.63$ & $138.0 \pm 1.36$ & $91.8 \pm 0.74$ \\
Irrad. & $23.0 \pm \mathbf{0 . 7 4}$ & $37.5 \pm 0.54$ & $77.7 \pm 0.97$ & $103.5 \pm 1.32$ & $91.8 \pm 0.80$ \\
$\mathbf{p}$ - value & $\mathbf{0 . 0 0 0}$ & $\mathbf{0 . 0 2 1}$ & $\mathbf{0 . 0 0 0}$ & $\mathbf{0 . 0 0 0}$ & $\mathbf{1 . 0 0 0}$ \\
Control & $34.5 \pm 0.94$ & $40.3 \pm 0.64$ & $109.9 \pm 0.63$ & $138.0 \pm 1.36$ & $91.8 \pm 0.74$ \\
Irrad. and dexa. & $33.0 \pm 0.83$ & $38.4 \pm 0.80$ & $104.2 \pm 2.03$ & $124.8 \pm 1.02$ & $89.5 \pm 1.25$ \\
$\mathbf{p}-$ value & $\mathbf{0 . 1 7 5}$ & $\mathbf{0 . 1 0 5}$ & $\mathbf{0 . 0 3 4}$ & $\mathbf{0 . 0 0 1}$ & $\mathbf{0 . 1 9 0}$ \\
Irrad. & $23.0 \pm \mathbf{0 . 7 4}$ & $37.5 \pm 0.54$ & $77.7 \pm 0.97$ & $103.5 \pm 1.32$ & $91.8 \pm 0.80$ \\
Irrad. and dexa. & $33.0 \pm \mathbf{0 . 8 3}$ & $38.4 \pm 0.80$ & $104.2 \pm 2.03$ & $124.8 \pm 1.02$ & $89.5 \pm 1.25$ \\
$\mathbf{p}-$ value & $\mathbf{0 . 0 0 0}$ & $\mathbf{0 . 1 9 9}$ & $\mathbf{0 . 0 0 1}$ & $\mathbf{0 . 0 0 0}$ & $\mathbf{0 . 2 7 9}$ \\
\hline
\end{tabular}

Table III. Mean thickness of the GL (mean \pm SEM) in micrometer $(\mu \mathrm{m})$.

\begin{tabular}{lccccc}
\hline Days / Group & $\mathbf{5}$ & $\mathbf{9}$ & $\mathbf{1 4}$ & $\mathbf{2 1}$ & $\mathbf{2 5}$ \\
Control & $49.6 \pm 0.78$ & $99.0 \pm 1.10$ & $106.5 \pm 1.13$ & $100.6 \pm 1.31$ & $86.8 \pm 1.79$ \\
Irrad. & $34.0 \pm 1.22$ & $92.4 \pm 1.49$ & $92.0 \pm 1.38$ & $99.0 \pm 1.33$ & $82.0 \pm 1.59$ \\
p- value & $\mathbf{0 . 0 0 0}$ & $\mathbf{0 . 0 2 7}$ & $\mathbf{0 . 0 0 0}$ & $\mathbf{0 . 5 2 3}$ & $\mathbf{0 . 0 4 4}$ \\
Control & $49.6 \pm 0.78$ & $99.0 \pm 1.10$ & $106.5 \pm 1.13$ & $100.6 \pm 1.31$ & $86.8 \pm 1.79$ \\
Irrad. and dexa. & $46.2 \pm 1.14$ & $92.0 \pm 1.16$ & $99.6 \pm 1.52$ & $99.2 \pm 1.50$ & $82.0 \pm 1.57$ \\
p- value & $\mathbf{0 . 0 4 2}$ & $\mathbf{0 . 0 1 1}$ & $\mathbf{0 . 0 1 0}$ & $\mathbf{0 . 3 2 2}$ & $\mathbf{0 . 0 9 9}$ \\
Irrad. & $34.0 \pm 1.22$ & $92.4 \pm 1.49$ & $92.0 \pm 1.38$ & $99.0 \pm 1.33$ & $82.0 \pm 1.59$ \\
Irrad. and dexa. & $46.2 \pm 1.14$ & $92.0 \pm 1.16$ & $99.6 \pm 1.52$ & $99.2 \pm 1.50$ & $82.0 \pm 1.57$ \\
p- value & $\mathbf{0 . 0 0 2}$ & $\mathbf{0 . 8 9 1}$ & $\mathbf{0 . 0 1 6}$ & $\mathbf{0 . 0 0 0}$ & $\mathbf{1 . 0 0 0}$ \\
\hline
\end{tabular}


The mean diameter of the Purkinje cell (PC) was significantly reduced in the irradiated as well as in the irradiated and dexamethasone group on days 14 and 21 compared with the controls at $\mathrm{p}<0.05$. However, no significant different was observed between the irradiated and dexamethasone group, and the irradiated group on days 5 , $9,14,21$ and 25 at $\mathrm{p}>0.05$ (Table IV).
Histologically, the cells of the ML in the irradiated group on days 9 and 14 were heavily gliosed compared to the mildly gliosed control, and the irradiated and dexamethasone groups. There was distortion of the PC monolayer with some cells found in either the ML or GL in the irradiated group on days 5, 9, 14 and 25. This however, was not seen when dexamethasone was administered to the irradiated animals (Figs. 1, 2 and 3).

Table IV. Mean diameter of the PC (mean \pm SEM) in micrometer $(\mu \mathrm{m})$.

\begin{tabular}{lccccc}
\hline Days / Group & $\mathbf{5}$ & $\mathbf{9}$ & $\mathbf{1 4}$ & $\mathbf{2 1}$ & $\mathbf{2 5}$ \\
Control & $5.8 \pm 0.43$ & $8.7 \pm 0.63$ & $11.6 \pm 0.86$ & $13.0 \pm 0.69$ & $13.3 \pm 1.03$ \\
Irrad. & $4.4 \pm 0.52$ & $6.6 \pm 0.47$ & $8.7 \pm 0.43$ & $10.2 \pm 0.76$ & $11.6 \pm 1.07$ \\
P - value & $\mathbf{0 . 0 5 8}$ & $\mathbf{0 . 0 7 1}$ & $\mathbf{0 . 0 4 1}$ & $\mathbf{0 . 0 0 1}$ & $\mathbf{0 . 3 2 2}$ \\
Control & $5.8 \pm 0.43$ & $8.7 \pm 0.63$ & $11.6 \pm 0.86$ & $13.0 \pm 0.69$ & $13.3 \pm 1.03$ \\
Irrad. and dexa. & $4.8 \pm 0.43$ & $6.7 \pm 0.49$ & $8.7 \pm 0.75$ & $10.6 \pm 0.74$ & $11.7 \pm 0.60$ \\
P - value & $\mathbf{0 . 2 1 4}$ & $\mathbf{0 . 0 6 8}$ & $\mathbf{0 . 0 1 3}$ & $\mathbf{0 . 0 0 5}$ & $\mathbf{0 . 1 1 9}$ \\
Irrad. & $4.4 \pm 0.52$ & $6.6 \pm 0.47$ & $8.7 \pm 0.43$ & $10.2 \pm 0.76$ & $\mathbf{1} 1.6 \pm 1.07$ \\
Irrad. and dexa. & $4.8 \pm 0.43$ & $6.7 \pm 0.49$ & $8.7 \pm 0.75$ & $10.6 \pm 0.74$ & $11.7 \pm 0.60$ \\
P - value & $\mathbf{0 . 3 3 3}$ & $\mathbf{0 . 8 6 9}$ & $\mathbf{1 . 0 0 0}$ & $\mathbf{0 . 6 4 1}$ & $\mathbf{0 . 9 2 4}$ \\
\hline
\end{tabular}

\section{DISCUSSION}

The developing central nervous system is known to be affected adversely by a variety of agents such as nutritional deficiency (Clark et al., 1973), alkylating agents (Maslinka, 1986), alcohol (West et al., 1990), cyanide (Pavlakovic, 1994), dexamethasone (Ferguson \& Holson, 1999) and irradiation (Sugihara et al.).

The EGL is the most metabolically active part of the developing cerebellum and its differentiation requires energy usually derived from body metabolism to produce the granule, outer stellate, basket and Golgi cells. Disruption of the energy generating pathways of the developing brain by any agent will ultimately affect cell differentiation. In this study, the EGL was significantly reduced in the irradiated group. The mechanism behind the reduction is unclear, but irradiation has been reported by Ferrer to cause cell death in the brain of young rats, and induced apoptosis in palatine shelves during secondary palate development causing palatal clefting (Hiranuma et $a l .$, 2000). However, the adverse effect of irradiation appeared to have been corrected when dexamethasone was administered to the irradiated animals. This could probably be due to its anti-inflammatory and membrane stabilizing effects as a steroid. Bhatt et al. reported that dexamethasone auguments lung maturation (including vascular development) in foetal and postnatal animals.
The ML of the cerebellar cortex becomes the most superficial layer with the complete disappearance of the EGL on postnatal day 21 in rats (Altman \& Bayer, 1978), and its thickness is determined by the amount of cells and fibres present (Rakic \& Sidman, 1970) but mainly by accretion of new parallel fibres (Rakic, 1971). The reduction in the thickness of the ML in the irradiated animals in not very clear but neuronal cell death in the GL or delayed parallel fibre formation caused by delayed granule cell formation could have affected the density of unmyelinated parallel fibres in the ML., and also may be due to the heavy gliosis observed in the ML of the irradiated group. A combination of irradiation and dexamethasone appeared to repair irradiation injury probably by its anti-inflammatory action on disrupted cell membranes.

The arrangement of PC into a monolayer is one characteristic feature, which occurs early in rat development and continues throughout life if not disrupted by external factors. (Altman \& Winfree, 1977) reported that by day $3-4$ postpartum, PCs have assembled into a monolayer. In this study, anon-uniform and inconsistent pattern of abnormal PC arrangement was observed in either or both the ML and GL in the irradiated animals. These were however, not seen in the control, and irradiated and 

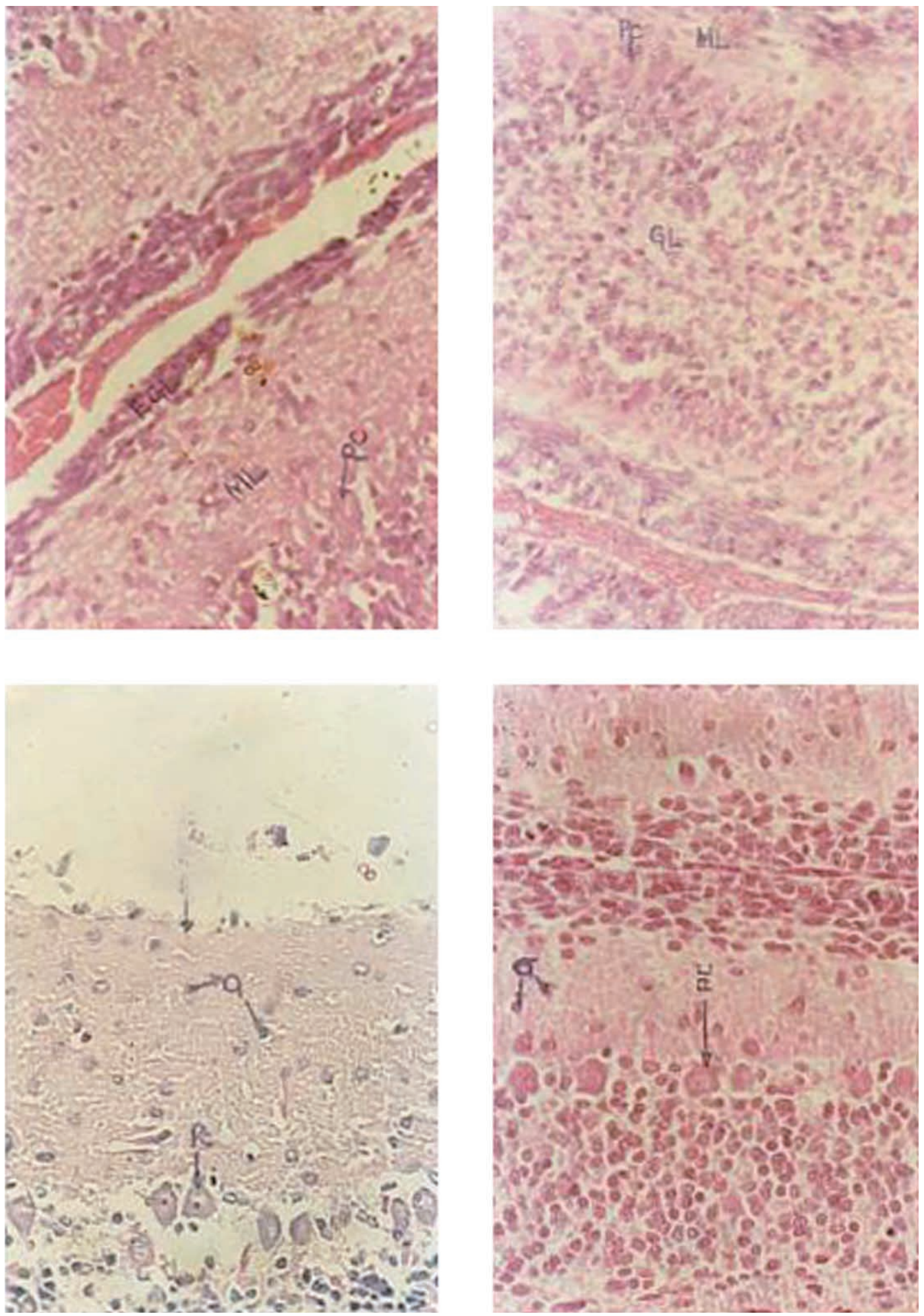

Pig. 1. Photomicrograph of the cerebellar cortex of control groups of (a). Postnatal day (PND) 5, (b). PND 9 , (c). PND 14 and (d). PND 25 showing normal monolayer of Purkinje cells, Pc and astrocytes, a. HE. X400. 

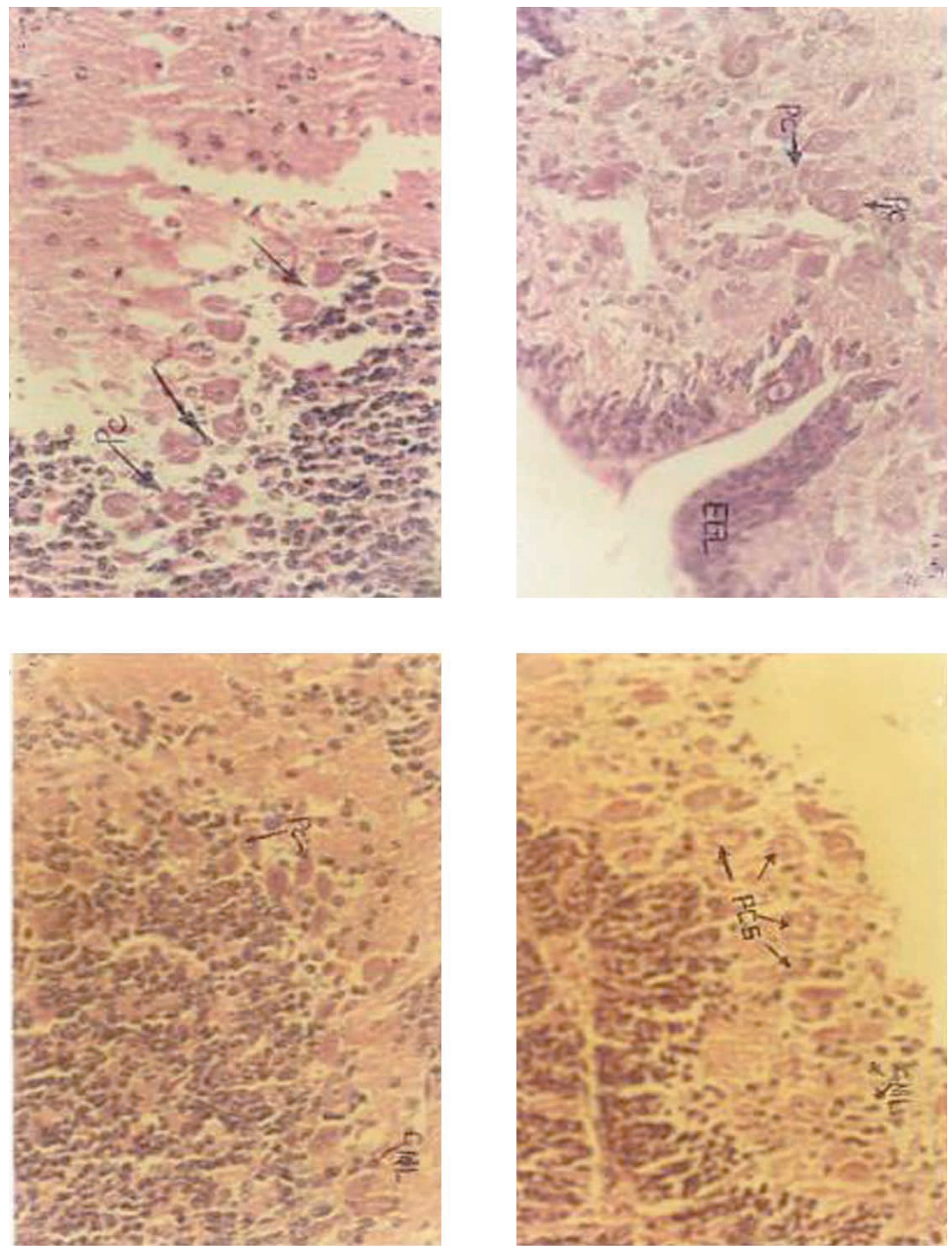

Fig. 2. Photomicrograph of the cerebellar cortex of irradiated group of (a). Postnatal day (PND) 5, (b). PND 9, (c). PND 14 and (d). PND 25 showing distorted Purkinje cells, Pc and heavily gliosed molecular layer, GML. HE. X400.

dexamethasone groups. The PC diameter was significantly reduced in the irradiated animals, but remained the same when dexamethasone was administered to the irradiated animals at the level of the present study.
In conclusion therefore, exposure of neonatal rats to a $5 \mathrm{~Gy}$ dose of irradiation results in distortion of the monolayer of the PC and heavy gliosis of the glial cells in the ML as well as a significant reduction in the thickness 

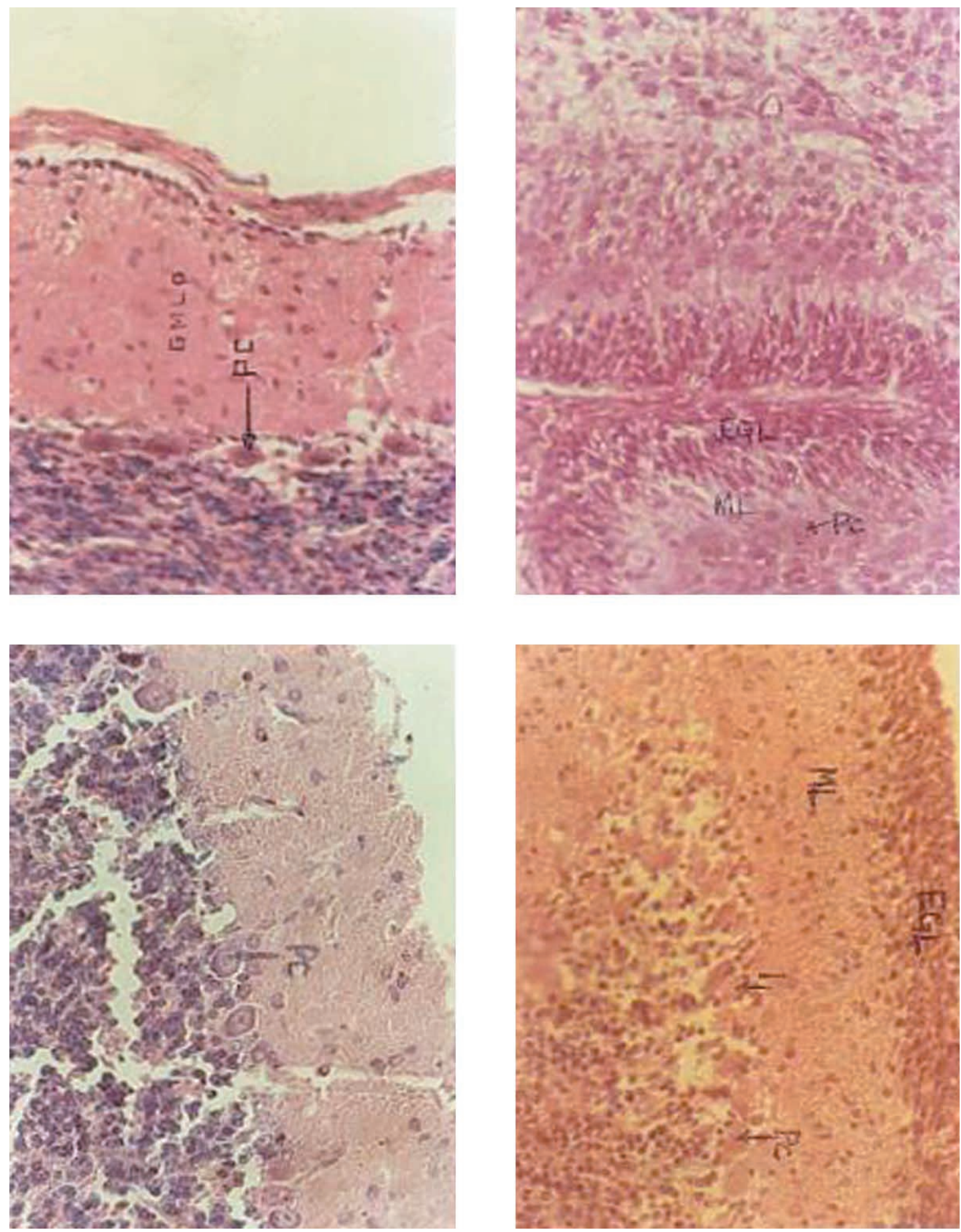

Fig. 3. Photomicrograph of the cerebellar cortex of irradiated and dexamethasone group of (a). Postnatal day (PND) 5, (b). PND 9, (c). PND 14 and (d). PND 25 showing normal monolayer of Purkinje cells, Pc and mildly gliosed ML. HE. X400.

of the EGL, ML and GL in the postnatal developing cerebellum of Wistar rats; and that the administration of dexamethasone one hour before exposure of the animals to irradiation tend to repair the damage caused by irradiation. 
MALOMO, A. O.; EKPO, O. E.; IMOSEMI, I. O.; OWOEYE, O.; OSUAGWU, F. C.; AVWIORO, O. G. \& SHOKUNBI, M. T. Efecto neuroprotector de la dexametasona sobre la morfología del cerebelo postnatal en desarrollo irradiado de rata Wistar (Rattus norvegicus). Int. J. Morphol., 24(2):221-229, 2006.

RESUMEN: Se estudió el efecto neuroprotector de la dexametasona, sobre el cerebelo post-natal en desarrollo irradiado de ratas Wistar. 75 neonatos de 1 día de edad fueron separados en 3 grupos; el grupo control no recibió ni drogas ni irradiación, un grupo irradiado y el otro irradiado con aplicación de dexametasona. Esta droga fue administrada una hora antes de la exposición de 5Gray (5Gy) de rayos gamma. El tejido cerebelar de cada grupo con 5, 9, 14, 21 y 25 días fueron procesados para estudios histológicos e histomorfométricos.

El resultado del estudio demostró que la sola irradiación redujo significativamente el grosor de la capa granular externa, en los grupos con 5 y 14 día,s con un $\mathrm{p} \leq 0,05$; la capa molecular en los ejemplares de 5, 9, 14 y 21 días con un $\mathrm{p} \leq 0,05$ y la capa granular en las ratas de 5,9,14 y 25 días, con un $\mathrm{p} \leq 0,05$. Cuando se combinó la dexametasona con irradiación, se observó un grosor significativamente diferente en la capa granular externa, en especímenes con 5, 9 y 14 días; en la capa molecular en los animales de 5, 14 y 21 días y en la capa granular en los que tenían 5 y 14 días, al compararlos con el grupo irradiado, con un p>0,05. El diámetro de las células de Purkinje (capa de Purkinje) aunque fue significativamente reducido en el grupo irradiado de 14 y 21 días, no fue significativamente diferente cuandos se administró dexametasona a los animales irradiados de 5, 9, 14, 21 y 25 días con un p $\leq 0,05$.

Histológicamente, las células de la capa molecular, en el grupo irradiado de 9 y 14 días, fueron marcadamente gliosadas comparadas con las medianamente marcadas en los grupos control e irradiados-dexametasona. Hubo distorsión de la monocapa de Purkinje, con algunas células encontradas en la capa molecular o en la capa de Purkinje, en el grupo irradiado de 5, 9, 14 y 25 días.

De los resultados de este estudio, se puede afirmar que la administración de 0,005 ml de dexametasona intraperitonealmente, una hora antes de una exposición a una irradiación, parece proteger el desarrollo del cerebelo de la rata, de lesiones producidas por irradiación.

\section{PALABRAS CLAVE: Morfología; Irradiación; Dexametasona; Desarrollo del cerebelo.}

\section{REFERENCES}

Altman, J. Morphological and behavioural markers of environmentally induced retardation of brain development: An animal model. Environmental Health Perspectives, 74:153-69, 1987.

Altman, J. \& Bayer, S. A. Time and distribution of a new cell type in the rat cerebellar cortex. J. Comp. Neurol. 179: 23-48, 1978.

Altman, J. \& Winfree, A. T. Postnatal development of the cerebellar cortex in the rat. V. spatial organization of Purkinje cell perikaryon. J. Comp. Neurol. 171:1-16, 1977.

Bhatt, A. J.; Amin, S. B.; Chess, P. R.; Watkins, R. H. \& Maniscalco, W. M. Expression of vascular endothelial growth factor and FIK-1 in developing and glucocorticoid- treated mouselung. Paediatric Research. 47 (5):606-13, 2000.

Brooks, W. C. Dexamethasone uses, dosages and side effects. Outline Pet Healthcare Library, 2001.
Clark, G. M.; Zahemhof, S.; Van Marthers, E.; Granel, L. \& Kragger, L. The effect of prenatalmalnutrition on dimensions of cerebral cortex. Brain Res. (54):397-402, 1973.

Doughty, M. L.; Delhaye-Bouchaud, N. \& Mariani, J. Quantitative analysis of cerebellar lobulation in normal and agranular rats. J. Comparative Neurology, 399 (3): 306-20, 1999.

Ferguson, S. A. \& Holson, R. R. Neonatal dexamethasone on day 7 causes mild hyper reactivity and cerebellar stunting. Neurotoxicology and toxicology, 21(1):71-6, 1999.

Ferrer, I. Cell death in normal developing brain and following ionizing radiation, methyl--azoxymethanol acetate and hypoxia-ischemia in the rat. (Review [40 Refs.]): Neuropathology and applied neurobiology, 22 (6): 489-94, 1996.

Grosch \& Hopwood : Biological Effects Of Radiation. ${ }^{\text {th }}$ ed., 1979. pp. 1-50. 
Hiranuma, H.; Jikko, A.; Maeda, T. ; Abe, M. \& Fuchihata, $\mathrm{H}$. Effects of secondary irradiation on secondary palate development in mice. Radiation easeach, 154(10):34-8, 2000.

Le Marec, N.; Dahhoaoni, M.; Stelz, T. et al. Effects of cerebellar granule cell depletion on spatial learning and memory in an avoidance conditioning task: Studies in postnatally X-irradiated rats. Fra-Dev. Brain Res., 99 (1):20-5, 1997.

Lidegran, M.; Domeiji, S.; Dahlqvist, A. et al. Irradiation influences the expression of substance-p and enkephalin in the rat larynx. Cell Tissue Res., 279 (1):55-63, 1995.

Maslinka, D. Effects of alkylating drugs on rat cerebellum. Folia Histochemica et Cytobiologyea, 24 (1):47-52, 1986.

Moore, K. L. \& Persaud, T. V .N. The Developing Human Clinically Oriented Embryology. An HBJ. International Edition. Saunders, 1998. pp 385-8.

Pavlakovic, G.; Rathinavelu, A. \& Isom, G. G. E. MK-801 prevents cyanide-induced changes of Fos levels in rat brain. Neurochemical Rresearch., 19(10):1289-94, 1994.

Rakic, P. Neuron-glia relationship during granule cell migration in developing cerebellar cortex:A Golgi and eletromicroscopic study in Macacus rhesus. J. Comp. Neur., 141:283-312, 1971.

Rakic, P. \& Sidman, R. L. Histogenesis of cortical layers in human cerebellum particularly the lamina dissecans. $J$. Comp. Neurol., 139-73, 1970.

Sadhler. Human Embryology. 5th ed. 1995. pp. 34-46.

Schull, W. J. Effects Of Atomic Radiation. Wiley-Liss Publishers, 1995. pp. 15-33.

Sugihara, I.; Bailly, Y. \& Mariami, J. Olivocerebellar climbing fibers in the granuloprival cerebellum: Morphological studies of individual axonal projections in the X-irradiation rat. J. Neuroscience, 20 (10):309 12,2000

West, J. R.; Goodlett, C. R.; Bonthius, D. J.; Hamre, K. M. \& Marcussen, B. L. Cell population depletion associated with fetal alcohol brain damage: Mechanisms of BACdependent cell loss. Alcoholism. Clinical and Experimental Research. 14 (6): 813 - 8, 1990.
Correspondence to:

Dr. I. O. Imosemi

Department of Anatomy

University of Ibadan

NIGERIA

E-mail:innosemi@yahoo.co.uk

Received: 12-10-2005

Accepted: 27-01-2006 
